\title{
BENCANA, AGAMA DAN KEARIFAN LOKAL
}

\author{
Oleh: \\ I Gusti Agung Paramita \\ Fakultas Ilmu Agama dan Kebudayaan \\ Universitas Hindu Indonesia \\ paramita@unhi.ac.id
}

\begin{abstract}
This article discusses disaster in the viewpoint of religion and local wisdom of Bali. In Balinese culture, between the bhuana agung and bhuana alit have an integralistic relationship. Whatever happens in the bhuana agung, has a direct relationship with bhuana alit - and vice versa. All kinds of ritual activities undertaken by Hindus in Bali to glorify and maintain cosmic balance are based on the emergence of a human consciousness centered on nature (cosmos). This is where ecocentrism comes into being. All human religious expressions are oriented towards the cosmos - purifying mountains, lakes, forests, and seas. In phenomenological perspective, the intentionality of human-centered consciousness of nature has shaped the beliefs and culture of Balinese society. Disaster awareness also emerges from this pattern. Balinese people use natural signs to explain the occurrence of the disaster. At least, this is implied in some texts, especially Roga Sangara Bumi, Bhama Kertih and Lebur Gangsa.
\end{abstract}

Keywords: Disaster, Religion, Local Wisdom

\begin{abstract}
Abstrak
Artikel ini membahas tentang bencana dalam sudut pandang agama dan kearifan lokal Bali. Dalam kebudayaan Bali, antara bhuana agung dan bhuana alit memiliki hubungan yang bersifat integralistik. Apapun yang terjadi di dalam bhuana agung, memiliki hubungan secara langsung dengan bhuana alit - begitu pula sebaliknya. Segala jenis aktivitas ritual yang dilakukan umat Hindu di Bali untuk memuliakan dan menjaga keseimbangan kosmik didasarkan pada munculnya kesadaran manusia yang terpusat pada alam (kosmos). Di sinilah ekosentrisme muncul. Segala ekspresi keagamaan manusia berorientasi pada kosmos - menyucikan gunung, danau, hutan dan laut. Secara fenomenologis, intensionalitas kesadaran manusia yang terpusat pada alam inilah membentuk kepercayaan dan kebudayaan masyarakat Bali. Kesadaran akan bencana juga muncul dari pola ini. Masyarakat Bali menggunakan tanda-tanda alam untuk menjelaskan terjadinya bencana. Setidaknya, hal ini tersirat dalam beberapa teks lontar khususnya Roga Sangara Bumi dan Bhama Kertih.
\end{abstract}

Kata kunci: Bencana, Agama, Kearifan Lokal

\section{PENDAHULUAN}

Masih ingat bencana yang meluluhlantakkan Bali pada Tahun 1963? Gunung Agung yang terletak di Karangasem kembali meletus - bisa dikatakan cukup dahsyat. Gumpalan asap membara, menyerbu lereng-lereng gunung. Lahar terbawa air menyapu lembah-lembah sungai, menuju laut dan menghancurkan sawah. Abu menutupi sebagian besar pulau. Gempa mengguncang Pulau Bali.

Angka-angka kematian dan kehancuran 
dipublikasikan beragam, tetapi paling sedikit 1.200 orang meninggal, ribuan binatang hangus, tujuh belas desa tersapu, lebih dari lima puluh ribu hektar tanah tidak berfungsi. Setidaknya inilah catatan David J. Stuart Fox, seorang peneliti Belanda dalam bukunya Pura Besakih: Temple, Religion, and Society in Bali. Satu hal yang menarik saat itu: umat Hindu di Bali sedang melaksanakan upacara besar Eka Dasa Rudra di Pura Besakih.

Sejarah ternyata terulang. Gunung yang dikenal dengan sebutan Tohlangkir ini, menunjukkan tanda-tanda erupsi di akhir tahun 2017. Kisah kelam letusan tahun 1963 membangun imaji historis masyarakat Bali. Ketakutan, kepanikan, keputusasaan menyelimuti diri masyarakat yang berada di bawah lereng Gunung Agung. Sampai awal tahuhn 2018, tanda-tanda erupsi Gunung Agung masih tampak, meski tak sedahsyat erupsi tahun 1963.

Bagi orang Bali, bencana meletusnya Gunung Agung ini bukanlah kebetulan - terdapat kepercayaan yang tersebar luas bahwa letusan tersebut menandai kemarahan dewa di Gunung tersebut. Tidak hanya itu, pada letusan-letusan Gunung Agung sebelumnya, juga dihubungkan dengan sikap kemarahan para dewa terhadap penguasa bumi. Artinya, peristiwa bencana alam tidak saja dianggap sesuatu yang terjadi begitu saja secara alamiah, melainkan ada sebab 'liyan' yang mengundang amarah dewa penguasa gunung sehingga mengakibatkan bencana. Penyebabnya beragam; bisa karena alpa menggelar ritual untuk para penguasa gunung, atau lantaran terjadi kekacauan politik di hilir.

Bisa dikatakan, dalam kepercayaan lokal khususnya umat Hindu di Bali saatitu, kekacauan yang dilakukan manusia ternyata bisa berdampak pada kekacauan semesta, begitu juga sebaliknya. Di titik inilah kesadaran manusia terpusat pada alam (khususnya pada gunung). Kesadaran yang terpusat pada alam ini membuat Gunung Agung menjadi salah satu titik suci yang harus 'disterilisasi' dan dilindungi dari hal-hal yang membuat kesuciannya terkontaminasi.

Berdirinya Pura Besakih menjadi salah satu penanda jika di kawasan tersebut tidak boleh diganggu dengan alasan apapun. Strategi pensucian dan pensakralan ini didukung pula oleh mitos-mitos yang menunjukkan betapa pentingnya posisi Gunung Agung dalam bentang orientasi kosmik Bali.

Menurut penulis, segala jenis aktivitas ritual yang dilakukan umat Hindu di Bali untuk memuliakan dan menjaga keseimbangan kosmik didasarkan pada munculnya kesadaran manusia yang terpusat pada alam (kosmos). Manusia sadar bahwa 'kemarahan' alam akan membawa bencana besar terhadap kehidupannya. Destruksi alam semesta juga akan berdampak pada kehidupan manusia. Di sinilah ekosentrisme muncul. Segala ekspresi keagamaan manusia berorientasi pada kosmos.

Umat Hindu di Bali sangat banyak memiliki ritual yang berakar pada ekosentrisme tersebut. Ritual tumpek bubuh, tumpek wariga, tumpek landep, candi narmada, bhumi suda, mapekelem, melabuh gentuh, ngerebeg, nangluk merana dan sebagainya adalah bentuk ekspresi keagamaan yang bertujuan untuk menjaga equilibrium dan memuliakan alam dan segala isinya (sarwa prani). Begitu pula upacara-upacara ritual yang dilaksanakan di Gunung (Giri), Laut (segara), Sungai (tukad), Danau (danu), dan Hutan (wana) adalah pengejawantahan dari kesadaran manusia yang berpusat pada alam.

Secara fenomenologis, intensionalitas kesadaran manusia yang terpusat pada alam inilah membentuk kepercayaan dan kebudayaan masyarakat Bali. Kesadaran yang terpusat pada alam ini juga mempengaruhi pola relasi dan hubungan antara manusia dan alam di Bali. Di sini sadar akan alam, berarti pula hormat akan alam. Hormat akan alam berarti juga siap melindunginya. Pada titik ini muncul hubungan yang 'puitis' dan 'intim' antara manusia dan alam. Relasi manusia dan alam bukanlah hubungan dualisme subyek dan obyek - yang satu menundukkan yang lain, melainkan hubungan yang resiprokal.

Ketika manusia sadar akan keberadaannya dalam dunia, maka ia wajib memelihara 'dunia'. Salah satu bentuk upaya 'memelihara' dunia oleh umat Hindu di Bali adalah dengan melaksanakan upacara ritual yang diperuntukkan pada alam dengan menggunakan sarana yang berasal dari alam pula. Selain itu, 'keintiman' manusia dengan alam di Bali membentuk manusia-manusia yang punya kepekaan terhadap gejala-gejala yang datangnya dari alam - termasuk salah satunya adalah akan terjadinya chaos atau bencana. Pada titik ini, 
bisa dikatakan hubungan manusia dan alam jadi sangat 'mistik'.

Namun guyubnya aktivitas ritual keagamaan yang diperuntukkan pada alam berbanding terbalik dengan realitas kehidupan manusia di Bali selama ini. Pada titik ini ada ketimpangan antara cita-cita ideal dan kenyataan. Paradigma pembangunan Bali yang bertendensi antroposentris dan berpusat pada rasionalitas manusia justru menempatkan alam pada posisi obyek yang bisa dibentuk, dieksploitasi, diperlakukan sesuai desain-desain akalrasional. Segala jenis aktivitas manusia pun berbasis teknologis-instrumental.

Alam dan segala isinya dianggap 'ada' untuk dieksploitasi secara ekonomis dengan cara-cara yang teknologis-instrumental. Di sini, hanya manusia yang dianggap memiliki nilai-nilai intrinsik, sedangkan alam hanyalah entitas fisik meteriil yang pasif. Hal ini terlihat sangat ambivalen dengan kebudayaan Bali yang ekosentris. Namun patut diakui umat Hindu di Bali sedang berada di tengah ketegangan tersebut.

Di satu sisi, masyarakat Bali masih sibuk dengan ritual yang bertujuan untuk memuja dan memuliakan alam semesta (bhuana agung), namun di sisi lain wajah-wajah industri produk dari modernitas semakin tidak ramah dengan lingkungan Bali. Di sini sedang terjadi ketidakseimbangan (disekuilibrium). Seperti dikatakan Leopold (dalam Dewi, 2015:5), ketidakseimbangan alam muncul karena kepesatan teknologi dan hiper-industrialisasi.

Perubahan yang mengatasnamakan manusia seringkali merusak ekuilibrium alam, dan ini sedang terjadi di Bali yang kaya akan praktik agama pemuliaan semesta. Jika bisa dikatakan, modernisasi kehidupan sehari-hari dengan perkembangan ilmu pengetahuan dan teknologi yang didasarkan pada prinsip rasionalitas justru membuat manusia kian berjarak dengan alam. Hubungan yang 'intim' dan 'mistik' menjadi sangat mekanistik. Tidak lagi ada chemistry antara manusia dan alam.

Ini pula yang menyebabkan belakangan Bali dilanda beberapa bencana yang cukup serius di musim penghujan. Kabupaten Buleleng digegerkan bencana banjir bandang bulan Februari lalu. Setidaknya ada lima desa yang porak-poranda akibat banjir bandang dan tanah longsor. Lima desa itu yakni Desa Musi,
Penyabangan, Sanggalangit, Banyupoh dan Pemuteran. Penyebab banjir (sesuai dilansir media onlie dan harian lokal) adalah rusaknya tangkapan air di daerah hulu tersebut. Areal hijau di pegunungan dan perbukitan mengalami kerusakan sehingga tak bisa menyerap air.

Hal ini tentu tak bisa dilepaskan dari 'biang kerok' bernama manusia. Aksi penebangan hutan, alih fungsi lahan yang dipaksakan untuk pembangunan akomodasi wisata dan perumahan, membawa efek bencana yang luar biasa. Ini salah satu fakta; jika hubungan manusia dan alam di Bali cenderung destruktif.

Konsep Wana Kertih, Tri Hita Karana, seolah hanya menjadi 'kata indah' yang jauh panggang dari api. Desa Adat dan masyarakat adat yang selama ini berperan sebagai tameng melawan perusakan lingkungan dengan norma-norma tradisional seakan tak berdaya oleh tangantangan kapitalis yang ingin mendisain alam berdasarkan hitung-hitungan ekonomis rasional. Padahal, perlakuan yang tidak 'puitis' terhadap alam tersebut berdampak pada bencana yang merugikan semua makhluk.

Selain itu, tercerainya keintiman hubungan manusia dan alam di Bali terlihat saat manusia menunjukkan 'sikap kaget' ketika terjadi peristiwa alam seperti halnya banjir dan banjir rob. Mereka tidak lagi memiliki kepekaan dan proteksi bencana - kesadaran akan Panca Baya. Ujung-ujungnya adalah upaya mencari 'kambing hitam'. Kemampuan membaca tanda bencana seperti barang langka saat ini.

Salah satu contoh, ketika terjadi banjir rob di pesisir Bali, masyarakat mendadak panik - dan menghubung-hubungkan ini dengan rencana reklamasi yang ramai menjadi isu publik. Padahal leluhur Bali punya banyak strategi membaca bencana. Selain dengan cara membaca sasih dan perhitungan waktu, tetua Bali juga membaca bencana dengan sipta (tanda) alam.

Dahulu banyak terdapat hutan pesisir pantai. Tujuan menghutankan pesisir pantai selain sebagai break water, juga memberi tanda ketika terjadi bencana. Logika sederhana: ketika air laut naik, maka makhluk/ekosistem yang hidup di hutan pesisir laut akan pergi ke hulu dan ini dibaca sebagai petanda terjadinya bencana di pesisir. Begitu juga sebaliknya, ketika akan terjadi letusan gunung, maka ekosistem hutan yang paling awal memberi pertanda kepada manusia. Artinya ada kemampuan membaca 
bencana hanya dangan sipta alam.

Namun saat ini disain pengelolaan pesisir pantai di Bali sudah berubah. Hutan pesisir pantai disulap menjadi hotel-hotel berbintang. Ada pula pesisir pantai yang dibangun break water beton dan jogging track. Jadi tidak ada sipta alam ketika terjadi bencana. Masyarakat pun hanya menggunakan prediksi teknologi ketika terjadi gelombang tinggi. Tetapi, korban jiwa tak terhindarkan. Dalam istilah orang Bali: ini adalah salah satu bentuk kasep tangkis bencana. Ini pula menunjukkan jika kesadaran kosmik manusia mulai hilang.

\section{PEMBAHASAN}

\subsection{Relasi Mistik Bhuana Agung-Bhuana Alit}

Dalam konsepsi kebudayaan Bali tentang kosmos, dikenal istilah bhuana agung dan bhuana alit. Bhuana agung dan bhuana alit bukanlah entitas yang bersifat dualismefragmentaris, melainkan dualitas yang korelasional dan berkesinambungan. Artinya, keduanya tidak dapat dipisahkan begitu saja, apalagi oleh akal pikiran. Inilah yang menunjukkan karakteristik integralistik dari kebudayaan Bali. Budaya Bali cenderung melihat keseluruhan dan keutuhan sebagai sesuatu yang utama. Individu atau bhuana alit, tidak memiliki peranan sendiri yang asali, ia harus menyesuaikan diri dengan kembali pada kosmos besar - bhuana agung (Usadi, 1989).

Masyarakat Hindu di Bali meyakini bahwa Tuhan menciptakan alam dengan mempergunakan lima benih unsur tenaga yang disebut pancatanmatra terdiri dari, Gandhatanmatra adalah benih unsur pertiwi, Rasatanmatra adalah benih unsur apah, Rupatanmatra adalah benih unsur teja, Sparsatanmatra adalah benih unsur bayu, Sabdatanmatra adalah benih unsur akasa.

Kelima jenis-jenis unsur yang disebut pancatanmatra itu kemudian masingmasing berubah menjadi atom-atom yang disebut Paramanu. Dari Paramanu itu muncullah unsur-unsur benda yang disebut Pancamahabhuta (lima unsur yang maha ada) yaitu, pertiwi adalah unsur zat padat, apah adalah unsur zat cair, teja adalah unsur sinar atau panas, bayu adalah unsur udara, akasa adalah unsur ether.
Bisa dikatakan antara bhuana alit dan bhuana agung tercipta melalui unsur-unsur yang sama yakni Pancamahabhuta. Interaksi bhuana agung dan bhuana alit ini terperantarai melalui tubuh manusia. Refleksi filosofis filsuf Prancis MerleauPonty menunjukkan manusia bertubuh adalah cara mengadanya di dunia. Sebelum disadari sebagai objek yang dikonseptualisasikan sebagai problematik fisiologis, yaitu sebagai segumpal daging, sebenarnya tubuh milikku merupakan suatu matra dari eksistensiku sendiri. Tubuh milikku itu kuhayati dan menyebabkan aku mendunia (Hardiman, 2002:78).

Jika mengacu pada refleksi filosofis tersebut, maka tidak heran jika tubuhlah yang pertama kali menerima sinyal-sinyal menyangkut sesuatu yang terjadi dalam jagat besar (bhuana agung). Rusak atau ketidakseimbangan yang terjadi dalam bhuana agung, maka akan berdampak pula pada bhuana alit. Bhuana alit mampu merasakan apa yang akan terjadi dalam bhuana agung. Pada titik ini, ada relasi mistik antara tubuh dan alam. Menurut penulis, ritual-ritual agama Hindu di Bali dengan sarana banten merupakan salah satu upaya menghidupkan kembali koneksi antara tubuh dan alam.

Bisa dikatakan, banten hanyalah sarana yang berfungsi untuk membangun kembali koneksi mistik tubuh dan alam. Selain juga perwujudan persembahan dan rasa bersyukur kepada pencipta. Hilangnya hubungan mistik antara tubuh dan alam ini, membuat manusia terasing - sehingga tidak lagi punya kepekaan jika akan terjadi bencana alam. Artinya, ketidakterlibatan dan penegasian pengalaman kebertubuhan dalam memanfaatkan dan memberdayakan alam-lingkungan, membawa resiko ekologis tertentu.

Dalam ritual-ritual Tantris, pengalaman kebertubuhan justru dijadikan salah satu jalan 'transendensi' atau penyerapan energi kosmis. Sebagaimana diketahui tantrayana sangat terkenal dengan ajaran Panca Ma, yaitu: (1) Matsya makan ikan; (2) Madya, minum minuman keras; (3) Mamsa, makan daging; (4) Mudra, gerakan-gerakan tertentu; (5) Maituna, hubungan seks, sebagai media pemujaan. Tujuannya adalah untuk mendapatkan kekuatan, kekuasaan, dan kesaktian (pengetahuan) dari Dewi Parwati sebagai Sakti Siwa (Surasmi, 2007). Dalam tradisi Tantris, sistem simbolis 
pemujaan melibatkan unsur-unsur kerbertubuhan, misalnya phalus dan vagina yang diperhalus menjadi bentuk Lingga Yoni (Utama, 2014).

Organ laki-laki menyimbolkan tindakan penanaman dan organ perempuan menyimbolkan bumi yang mengandung buah. Ketika tubuh manusiawi dan bumi diasumsikan memiliki sifat-sifat kesamaan alami, keduanya harus dipahami sebagai berinteraksi dan tergantung. Misteri alam oleh karena itu harus menjadi misteri tubuh manusia. Tubuh manusia menjadi mikrokosmos jagad raya, dan ini diperhitungkan untuk kosmogoni Tantra yang bertujuan untuk menjelaskan kelahiran Jagad Raya di dalam pengertian misteri kelahiran pengada manusiawi (Utama,2014).

Hubungan antara manusia dengan alam diniscayakan terjadi dalam keadaan yang harmonis, seimbang antara unsur-unsur yang ada pada alam dan unsur-unsur yang dimiliki oleh manusia. Keseimbangan inilah yang selalu mesti dijaga, dan salah satu cara yang ditempuh adalah dengan melakukan yadnya. Dalam konteks hubungan manusia dengan lingkungan (alam, binatang dan tumbuh-tumbuhan) pada masyarakat Bali misalnya, ada upacara Tumpek Bubuh dan Tumpek Kandang.

Dasar filosofis Tumpek Bubuh berpijak pada sikap untuk memberi sebelum menikmati, dalam konteks dengan pelestarian sumber daya hayati, sebelum manusia menikmati dan menggunakan tumbuh-tumbuhan sebagai bagian menu makanan haruslah diawali dengan proses penanaman dan pemeliharaan, misalnya seorang petani sebelum menikmati nasi, ia terlebih dahulu menanam padi. Seperti halnya Tumpek Bubuh, Tumpek Kandang juga menawarkan kepada kita untuk selalu mencintai segala jenis satwa, dan dasar filosofis Tumpek Kandang berpegang pada ajaran bahwa manusia dengan lingkungan ibarat macan dengan hutan, macan adalah penjaga hutan dan hutanpun menjaga macan. Jika tidak saling menjaga maka akan berbuah bencana.

Hal ini juga sejalan dengan falsafah Jawa. Dalam falsafah Jawa disebutkan menjaga keindahan alam dinyatakan dalam Mamayu Hayuning Bhawana. Ayuning manungso gumantung marang ayuning bawono. Ayuning bawono gumantung marang ayuning samudoyo (Wiryatnaya, 2006). Artinya kebaikan dan keindahan hidup manusia tergantung pada kebaikan dan keindahan kosmos sebagai buana. Kebaikan dan keindahan buana tergantung pada kebaikan dan keindahan seluruh unsur realitas. Keberadaan, sebaran sumber sumber air dan dan kualitas air merupakan salah satu busana alam.

\subsection{Tanda Bencana dalam Roga Sanghara Bhumi dan Bhama Kertih}

Menurut Ninian Smart (dalam Sudiarja, 2006: 32) ada tujuh dimensi setiap agama. Dimensi pertama adalah dimensi praktis-ritual sebagaimana tampak dalam upacara suci, perayaan hari besar, kebaktian dan sebagainya. Dimensi kedua, emosional eksperiensial menunjuk pada perasaan dan pengalaman para penganut agama yang bervariasi. Peristiwaperistiwa khusus, gaib, dan luar biasa yang dialami para penganut menimbulkan berbagai macam perasaan dari kesedihan dan kegembiraan, kekaguman dan sujud.

Topik yang penting dalam dimensi pengalaman keagamaan antara lain disebut mistik-dimana si pemeluk merasakan kesatuan erat dengan yang ilahi. Yang ketiga adalah dimensi naratif yang menyajikan kisah-kisah suci untuk direnungkan, selanjutnya yang keempat adalah dimensi filosofis doktrinal yakni dimensi agama yang menyajikan pemikiran rasional, argumentasi, penalaran menyangkut ajaran-ajaran agama, pendasaran hidup dan pengetrian konsep-konsep yang dianut agama.

Dimensi kelima yakni dimensi legal-etis menyangkut tata tertib hidup dalam agama, pengaturan bersama dengan norma peraturan, tidak jarang pula disertai dengan sistem penghukuman kalau terjadi pelanggaran. Keenam adalah dimensi sosial-institusional mengatur kehidupan bersama menyangku pemerintahan, organisasi, penasbisan pemimpin, dan hal-hal institusional dalam agama, terakhir adalah dimensi material menyangkut barang-barang, alat yang digunakan dalam pemujaan, termasuk bangunan-bangunan tempat ibadat.

Mengacu pada pandangan Ninian Smart di atas tentang agama, maka dalam konteks kebencanaan, agama menawarkan dimensi filosofis doktrinal sebagai perspektif. Dalam konteks agama Hindu di Bali, ada beberapa teks 
sastra yang di dalamnya berisikan ajaran-ajaran untuk memahami tanda-tanda bencana dan upaya yang dilakukan. Setidaknya ada dua teks lontar yang diacu dalam makalah ini, yakni Roga Sanghara Bhumi dan Bhama Kertih.

Dalam Roga Sanghara Bhumi dibabarkan bahwa yang menyebabkan hancurnya dunia adalah marahnya Bhatara Druwaresi yang berstana di atas langit dan Sanghyang Anantasana yang berstana di Sapta Petala. Beliau sangat marah dengan manusia di dunia. Tanda bumi mengalami kehancuran; api membesar, segala golongan bhuta pisaca menjelma sebagai manusia, dunia menjadi kacau balau, orang tidak berkesadaran, bermusuhan dengan saudara, orang-orang yang menjalani dharma mendapat celaan.

Bentuk kelahiran binatang yang tidak biasa muncul (salah timpal) karena anjing bersetubuh dengan sapi babi, kerbau bersetubuh dengan sapi, sering terjadi gempa, mantra tidak manjur, racun merajalela, bumi dipenuhi kekotoran, ternodai sampai ke dunia bawah. Marahlah Sanghyang Anantabhoga diinjak punggungnya oleh manusia kotor sehingga punggung beliau panas. Kemudian bergeraklah ekor beliau sehingga bumi bergetar. Ini sebagai isyarat akan terjadi bencana buruk di bumi - termasuk gempa bumi. Di sini umat manusia harus melaksanakan upacara 'Bhumi Suddha' penyucian dunia.

Roga Sanghara Bhumi menjelaskan tandatanda wabah berdasarkan perhitungan sasih. Bila pada sasih kaenem datangnya gempa secara terus-menerus, itu sebagai pengundang wabah penyakit. Datangnya penyakit diawali dengan panas, gelisah, menggigil. Penyakit itu datang dari Bhatara Luhuring Akasa. Maka manusia patut mempersembahkan caru di pinggir selatan desa.

Bila pada sasih kepitu datangnya sakit, bermacam-macam penyakit, itulah Bhatara Guru yang menyebarkan penyakit. Patut mempersembahkan caru. Selanjutnya, bila pada sasih kaulu dan katiga datangnya gempa secara terus menerus, sebagai pengundang penyakit dan wabah pada desa-desa di tepi pantai, itu wabah yang disebarkan oleh Bhatara Surya, Bhatara Baruna, maka patut melaksanakan upacara guru piduka di segare. Begitu pula dengan sasih-sasih yang lainnya. Ketika terjadi bencana dalam dalam bentuk wabah penyakit atau bencana alam, maka Roga Sanghara Bumi menawarkan penyelesaian ritual dengan cara mecaru dan melakukan upacara guru piduka.

Roga Sanghara Bhumi juga memberi isyarat pada Raja tentang ciri-ciri bumi ditimpa alamat yang tidak baik dan berdampak pada kehidupan raja, seperti ketika ada pelangi masuk ke keraton, maka pertanda raja akan hancur dan berumur pendek. Begitu pula apabila binatang kidang, menjangan, berlari masuk ke desa pakraman, maka itu isyarat buruk. Menandakan desa itu katadah kala (dimakan kala). Kidang itu diperintahkan oleh Sanghyang Kaliyuga untuk masuk ke desa. Maka desa akan mengalami bencana. Untuk mengantisipasi terjadi bencana, sekali lagi, Roga Sanghara Bhumi menawarkan penyelesaian ritual dengan cara mecaru.

Belum selesai di situ. Dalam lontar ini disebutkan, bila ada pohon besar tumbang tidak karena diterjang topan, maka rakyat akan mengalami kehancuran. Begitu pula bila ada bintang berekor - yang sering disebut bintang kukus - di langit mengisyaratkan sang murdaning jagat akan tertimpa bahaya. Lagi jika ada sungai banjir besar, disertai hujan lebat sehingga pohon beringin roboh - sampai dasar laut tertimbun maka mengisyaratkan raja akan tewas dalam pertempuran.

Selanjutnya, jika makhluk sebumi terkena penyakit anda kacacar disertai datangnya teluh, desti, dan magik yang merajalela - sampai masyarakat di pesisir barat-selatan terkena penyakit berat itu racun yang ditebar Hyang Baruna. Di sini umat manusia diminta untuk melakukan persembahan di tengah laut. Umat Hindu di Bali menyebut upacara ritual ini melabuh gentuh - yang dilakukan pada sasih kasanga.

Dalam Roga Sanghara Bhumi memang ditekankan pentingnya peran seorang pemimpin dalam menjaga harmoni dunia dan alam dengan mengedepankan pada praktik-praktik ritual keagamaan. Jadi segala bentuk tanda-tanda bahaya yang datangnya dari alam, mesti diselesaikan dengan jalan mempersembahkan upacara dalam bentuk caru. Tujuannya adalah memohon keselamatan, keharmonisan, kedamaian dunia, dan yang terpenting adalah keseimbangan alam. Seorang pemimpin yang punya otoritas tradisional, memegang peran strategis di sini.

Seperti yang disampaikan dalam Roga 
Sanghara Bhumi; apabila raja menginginkan kerahayuan bumi, patut mempersembahkan guru piduka, memohon keselamatan negara, kepada dewa gunung di Besakih yang dikenal dengan sebutan Bhatara Putrajaya, kepada dewanya laut di Ulun danu, dan Bhatara Baruna di laut. Ketiga tempat ini menjadi orientasi kosmik Bali yang harus dijaga kesuciannya - jika tidak maka akan memunculkan bencana. Roga Sanghara Bhumi mengisyaratkan agar pemimpin melaksanakan upacara labuh gentuh di laut dan di danau, dan melaksanakan Panca walikrama di Besukih. Jadi jelas bahwa lontar ini ditulis untuk memberikan isyarat dan 'alarm' bagi raja dalam mengupayakan keseimbangan dan keharmonisan jagat. Tidak hanya jagat besar bhuana agung, melainkan juga jagat kecil bhuana alit.

Pemahaman yang hampir sama juga terdapat dalam teks Bhama Kertih. Namun teks lontar ini lebih banyak memberikan pedoman mendirikan wewangunan dari rumah sampai pada tempat suci. Di dalam lontar ini juga dijelaskan kategori dan ciri-ciri karang panes yang tidak layak di atasnya didirikan wewangunan karena akan berdampak pada munculnya marabahaya atau bencana. Selain itu, untuk mengupayakan kerahayuan jagat, dalam Bhama Kertih juga dijelaskan ritual pamendeman (mendem Panca Dhatu) untuk penguat dunia/pengukuhan bumi.

Bhama Kertih mengisyaratkan tanda-tanda karang panes sebagai berikut: bila ada asap keluar dari dalam tanah pekarangan, tanah pekarangan yang langsung ditembus oleh lorong, jalan raya, sungai, berdampingan dengan perempatan, dengan pura, bale banjar berada di hulu tanah itu, maka tanah itu disebut sebagai karang panes yang menyebabkan marabahaya apabila dibangun rumah di atasnya. Dan lagi bila ada binatang yang bersenggama di dalam rumah, tawon bersarang di dalam rumah, begitu pula ular masuk ke rumah, maka ini termasuk dalam sipta akan terjadinya bencana dan menunjukkan bahwa pekarangan itu panas.

Selanjutnya Bhama Kertih melarang penggunaan kayu bekas terbakar untuk digunakan sebagai bahan wewangunan. Karena akan menyebabkan marabahaya bagi orang yang akan menghuni bangunan tersebut. Selain itu, dalam Bhama Kertih juga disebutkan bahwa jika ada pohon besar yang disambar petir, maka di tempat itu wajib mendirikan Padma Capah stana Bhatara Indra Blaka supaya masyarakat tidak mengalami kesengsaraan - selain juga merupakan upaya pamangguh pamali. Jadi Bhama Kertih menggunakan istilah karang panes sebagai sebab dari adanya bencana atau marabahaya. Senada dengan Roga Sanghara Bumi, Bhama Kertih juga menawarkan dimensi materiil dari agama yakni upacara ritual dengan beraneka jenis sesajen yang bertujuan untuk pemangguh pemali atau pemangguh bhaya untuk keseimbangan dan keharmonisan dunia.

\subsection{Implementasi Konsep Sad Kertih}

Sebenarnya, umat Hindu di Bali sangat banyak memiliki value dan ajaran untuk menjaga ekosistem alam. Selain mengenal konsep Tri Hita Karana, umat Hindu di Bali juga memiliki ajaran yang dikenal dengan Sad Kertih. Perihal Sad Kertih ini dirumuskan dalam lontar Purana Bali. Adapun keenam hal yang harus dilakukan yakni: Atma Kertih, Samudra Kertih, Wana Kertih, Danu Kertih, Jagat Kertih dan Jana Kertih.

Atma Kertih menyangkut kehidupan Sang Hyang Atma yang harus dijaga kesuciannya dari belenggu Tri Guna. Umat Hindu di Bali melaksanakan penyucian atma orang yang meninggal dengan upacara Pitra Yadnya dari ngaben, mamukur sampai pada ngelinggihang Dewa Hyang. Proses penyucian Atma ini dimungkinan apabila tempat-tempat penyucian atma juga dalam keadaan bersih dan suci.

Maka Atma Kertih juga sangat berhubungan dengan Samudra Kertih yakni pelestarian Samudra. Umat Hindu di Bali memiliki tradisi membuang abu jenazah di lautan. Selain itu, umat Hindu juga memanfaatkan laut sebagai tempat pengelukatan segala mala atau kekotoran di dalam diri. Ini dimungkinkan dilakukan apabila laut dalam keadaan yang bersih dan suci. Maka dari itu, melakukan penyucian laut sangat penting dan menjaga kebersihannya.

Bayangkan saja, jika samudra rusak, pantai diterjang abrasi, pesisir dikapling untuk pembangunan hotel, maka akan sangat berdampak bagi kehidupan rohani umat Hindu di Bali. Namun kenyataannya, pantai-pantai di Bali kian banyak tercemar. Pantai seolah jadi muara segala jenis limbah baik rumah tangga maupun industri. Biota laut dan sumber hayati pun rusak. Fakta ini berbanding terbalik dengan agama orang Bali yang berorientasi pada laut. Umat Hindu melakukan upacara makelem dan 
melabuh gentuh di segare memohon pada Dewa Baruna agar tidak terjadi bencana laut dan meniscayakan dunia dalam keadaan harmoni.

Demikian pula dengan Wana Kertih, sebuah upaya untuk melestarikan hutan. Leluhur kita di masa lalu banyak membangun pura di tengah hutan dan umumnya disebut Pura Alas Angker. Alas berarti hutan atau wana. Angker sama dengan angker bahasa Indonesia dimaksudkan sebagai tenget dalam bahasa Bali. Dengan adanya pura Alas Angker ini, masyarakat pun diharapkan mengangkerkan hutan sehingga tidak ada perusakan.

Dalam kitab Pancawati ada tiga cara untuk melestarikan hutan. Yakni: Mahawana, Tapawana dan Sriwana. Mahawana adalah hutan sebagai sumber hayati, sebagai penyimpan air sepanjang tahun. Dengan hutan yang baik air hujan disimpan untuk tetap disalurkan di musim kering. Bencana banjir bandang yang terjadi di Kabupaten Buleleng menunjukkan jika hutan tidak lagi berfungsi sebagai daerah tangkapan air. Penebangan liar dan pembukaan hutan sebagai pemukiman atau akomodasi pariwisata menyebabkan bencana itu terjadi. Padahal dulu, dalam konsep Mahawana orang menebang pohon di hutan dikenai denda. Seperti di Desa Adat Tenganan Pengringsingan.

Selanjutnya Tapawana artinya hutan tempat orang-orang suci membuat tempat pertapaan atau sekarang mungkin tempat meditasi atau pasraman. Diharapkan para pengikut (sisya) orang suci itu berdatangan ke hutan dan bersama-sama menjaga hutan. Doa yang dilantunkan juga memberi vibrasi pada kelestarian hutan. Sekarang bukan orang suci yang membangun pasraman di hutan, tetapi investor yang membangun vila di hutan. Sriwana adalah hutan sebagai sumber kemakmuran masyarakat. Hutan apabila dijaga kelestariannya dan ekosistem di dalamnya memang akan mampu memenuhi kebutuhan hidup manusia. Bukan justru sebaliknya dengan memperlakukan hutan sebagai obyek yang dieksploitasi dengan cara-cara destruktif. Perlakuan destruktif terhadap hutan Bali, akan berdampak destruktif pula terhadap kehidupan manusia.

Kertih selanjutnya adalah yakni Danu Kertih. Ini suatu upaya untuk menjaga kelestarian sumber-sumber air tawar di danau. Danau seringkali dijadikan tempat ritual mekelem (menenggelamkan hewan korban). Di setiap danau ada pura yang biasa disebut Pura Ulun Danu. Namun upaya kelestarian danau di Bali juga jauh panggang dari api. Buktinya danau-danau di Bali terus mengalami sedimentasi. Ini yang menyebabkan air danau meluap. Seperti yang pernah terjadi di Tamblingan dan Kintamani Bangli. Ini menunjukkan, jika konsep Danu Kertih belumlah terimplementasi dengan baik. Akhirnya, terjadi bencana naiknya air danau yang merugikan manusia pula.

Kertih yang kelima yakni Jagat Kertih. Yang dimaksud Jagat Kertih adalah upaya untuk melestarikan keharmonisan hubungan sosial di masyarakat. Para leluhur kita menerjemahkan Jagat Kertih ini dengan membangun Desa Pekraman. Membangun keharmonisan sosial yang dinamis dalam masyarakat Hindu di Bali lewat Desa Pakraman yang bercirikan adanya Tri Kahyangan. Yang terakhir adalah Jana Kertih. Upaya membangun manusia yang memiliki kepekaan dan kesadaran dalam merawat lingkungan hidup. Jika saja Sad Kertih ini diimplementasikan dalam upaya pencegahan dini terjadi bencana, maka resiko dari terjadinya bencana bisa dikurangi.

\section{PENUTUP}

Dalam kebudayaan Bali, antara bhuana agung dan bhuana alit memiliki hubungan yang bersifat integralistik. Apapun yang terjadi di dalam bhuana agung, memiliki hubungan secara langsung dengan bhuana alit - begitu pula sebaliknya. Segala jenis aktivitas ritual yang dilakukan umat Hindu di Bali untuk memuliakan dan menjaga keseimbangan kosmik didasarkan pada munculnya kesadaran manusia yang terpusat pada alam (kosmos). Di sinilah ekosentrisme muncul. Segala ekspresi keagamaan manusia berorientasi pada kosmos - menyucikan gunung, danau, hutan dan laut. Secara fenomenologis, intensionalitas kesadaran manusia yang terpusat pada alam inilah membentuk kepercayaan dan kebudayaan masyarakat Bali. 


\section{DAFTAR PUSTAKA}

Abdulah, Irwan. 2006. Konstruksi dan Reproduksi Kebudayaan. Yogyakarta: Pustaka Pelajar.

Adlin, Alfathri (Ed.). Menggeledah Hasrat. Bandung: Jalasutra.

Bhattacharyya, Narendra Nath. 1975. History of Indian Erotic Literature. New Delhi: Munshiram Manoharial Publishers Pct.Ltd.

Budi Utama, I Wayan. 2015. Air, Ritual dan Tantrisme di Bali dalam Revitalisasi Agama Tirtha di Bali (A.Paramita, ed). Denpasar: Fakultas Agama, Pascasarjana Unhi.

, 2013. Agama dalam Praksis Budaya. Pascasarjana Universitas Hindu Indonesia Denpasar.

Dewi, Saras. 2015. Ekofenomenologi: Mengurai Disekuilibrium Relasi Manusia dengan Alam. Tangerang: Marjin Kiri.

Darma Putra, Ketut Gde. 2010. Pencemaran Lingkungan Ancam Pariwisata Bali. Denpasar: Manikgeni. Geertz, Clifford. 1992. Tafsir Kebudayaan. Yogyakarta: Kanisius.

Hardiman, F. Budi. 2007. Filsafat Fragmentaris. Yogyakarta: Kanisius.

Hadiwijono. 2010. Agama Hindu dan Budha. Jakarta: BPK Gunung Mulia.

Heidegger, Martin. 1971. Poetry, Language, Thought. New York: Harper and row Publisher.

Holt, Claire. 1967. Melacak Jejak Perkembangan Seni di Indonesia. Bandung: Arti-Line

Russel, Betrand. 2002. Sejarah Filsafat Barat. Yogyakarta: Pustaka Pelajar

Sugiharto, dan Rahcmat. 2000. Wajah Baru Etika dan Agama. Yogyakarta: Kanisius.

Susanti, Ninie, dkk. 2013. Patirthan Masa Lalu dan Masa Kini. Jakarta: Wedatama Widya Sastra.

Sumarta, I Ketut. 2015. BATUR: Jantung Peradaban Air Bali. Denpasar: Wisnu Press.

Soebadio, Haryati. 1971. Jnana Siddhanta. Belanda: Koninklijk Instituut voor Taal, Land-en Volkenkunde.

Mantra, I.B., 1996. Landasan Budaya Bali. Denpasar: Yayasan Dharma Sastra.

Nala, I Gusti Ngurah. 1992. Usada Bali. Denpasar: PT. Upada Sastra. 